\title{
STUDY OF RESISTANCE TO ANTIBIOTICS OF MICROORGANISMS ISOLATED FROM ANTARCTIC CLIFFS AND BLACK SEA BOTTOM SEDIMENTS
}

\author{
N.A. Matvieieva, L.N. Churkina, A.M. Shakhovsky, S.V. Kadurin, A.B. Tashyrev
}

\begin{abstract}
Resistance to antibiotics of bacteria isolated from extreme ecosystems was compared. Pseudomonas antarctica and Rothia sp. strains isolated from rocky lichen of Antarctic Galindez Island were highly resistant to the antibiotics. Rhodococcus fascians 181n3, Sporosarcina aquamarina 188n2 and Staphylococcus epidermidis 190n1 strains were found to be sensitive to all antibiotics studied. Plasmid localization of genes coding resistance to $\mathrm{Cr}$ (VI) and $\mathrm{Co}^{2+}$ was determined. Correlation of resistance of microorganisms isolated from «ecologically pure» ecosystem to antibiotics demonstrated in this study and resistance of these microorganisms to the toxic metals exhibited by us earlier is fundamentally new data which testify the phenomenon of simultaneous resistance of microbial community to different extremal factors.
\end{abstract}

Keywords: microorganisms, Antarctic cliffs, antibiotic resistance, toxic metal resistance

\section{INTRODUCTION}

Antarctica is a continent with unique climatic features. A combination of extreme factors is always present here (sharp daily temperature differentials, strong winds, high level of UV radiation). Microbial communities on vertical rocky scarps (referred to as cliffs) are affected by these extreme factors to the fullest extent. Besides, an extremely uneven distribution of organic compounds is observed in biofilms on cliffs. This presumes a competition between microorganisms for nutrient sources and as a result the expressed phenomenon of antibiosis. Antibiosis shows itself in two ways: on the one hand it is a synthesis of antibiotics by microorganisms; on the other hand it is a resistance to them. Furthermore antibiosis is strengthened as a result of high concentrations of microorganisms in biofilms. After all, lichens, bacteria, micromycetes, which are the components of cliff phytocenoses, produce organic acids which mobilize metals from effusive rocks. The presence of these factors leads to a formation of relevant adaptive or protective mechanisms in microorganisms. The ecosystem of the Black Sea abyssal zone sediments is surely considered to be an extreme one, but it significantly differs from Antarctica by its conditions (physicochemical factors). Bottom deposits of the Black Sea miss $\mathrm{O}_{2}$, solar radiation and temperature differentials. High concentration of microorganisms in biofilms on Antarctic cliffs and in the Black sea bottom mud is a common feature for both ecosystems. This is supposed to be a source of antagonism and antibiosis phenomena in microbial communities in these ecosystems, which differ so much from each other.

We consider antibiotics to be a separate class of extreme factors together with UV radiation, toxic metals, etc. That is why the study of the Antarctic and
Black Sea microbial communities' resistance to antibiotics allows revealing the common regularities of microbial communities' resistance to these extreme biological factors. It is necessary to mention that microbial communities are subject to a simultaneous impact of the mentioned factors in natural extreme ecosystems. That is why it was interesting to compare the resistance of Antarctic cliff microorganisms at least to two types of extreme factors, i.e. to antibiotics and toxic metals. Moreover, it is well known that the resistance to toxic metals correlates with the resistance to antibiotics [1-3].

Earlier we found out that microorganisms, isolated from the Galindez Island cliffs lichen samples, possess high resistance to UV radiation [4], as well as they are highly resistant to toxic metals $-\mathrm{Co}^{2+}, \mathrm{Ni}^{2+}, \mathrm{Cu}^{2+}, \mathrm{Hg}^{2+}$, $\mathrm{Cr}(\mathrm{VI})[5,6]$. That is why we have studied the resistance profile of bacteria isolated from Antarctic cliffs and from the Black Sea bottom sediments sample (depth $806 \mathrm{~m}$ ) to a wide spectrum of antibiotics, as well as we have selected the strains, which are resistant both to antibiotics and to toxic metals.

The evaluation of resistance of microorganisms isolated from Antarctic cliffs and Black Sea bottom sediments to different antibiotics was the aim of this study.

\section{MATERIALS AND METHODS}

12 strains of aerobic chemoorganotrophic bacteria isolated form soils and phytocenoses of Argentine Archipelago Islands (Antarctica, Near Antarctic Peninsula, Ukrainian Antarctic Station "Akademik Vernadsky") were the object of research. Microorganisms are represented by the following species: Pseudomonas fluorescens 180n1, Microbacterium foliorum 181n2, Rhodococcus fascians 181n3, Sporosarcina aquamarina 182n1, $S$. 
aquamarina $188 \mathrm{n} 2, \quad$ Brevundimonas vesicularis 187n3, Staphylococcus sp. 190n1, Rothia sp. 190n2, Micrococcus luteus 3201, Enterobacter hormaechei 3202, Brevibacterium antarcticum 3204, Microbacterium trichothecenolyticum 3208. Earlier they were isolated from rocky lichens, sampled from the different stationary monitoring points on rocks and from soils of Galindez island [7-9].

Paenibacillus barcinonensis 3225 culture, isolated from the Black Sea bottom sample (depth $806 \mathrm{~m}$ ), was also investigated. Microorganisms were cultivated on the solidified Nutrient Agar medium (NA of HiMedia Laboratories Pvt. Ltd company) at $28^{\circ} \mathrm{C}$ during 24 hours.

Sensitivity of Antarctic strains to antibiotics was determined by means of Kirby-Bauer disk diffusion test [10]. The results were evaluated by diameter of the area free from microorganism growth.

Plasmid DNA was separated from Microbacterium trichothecenolyticum 3208 (plasmid $\mathrm{P} 08 \mathrm{Co}$ ) and Enterobacter hormaechei 3202 (plasmid $\mathrm{P} 02 \mathrm{Cr}$ ). The cultures were cultivated in NB nutrient broth medium (HiMedia Laboratories Pvt. Ltd.) at a temperature of $28^{\circ} \mathrm{C}$ on a shaker (200 r.p.m.) during 24 hours. Bacterial suspensions were centrifuged ( $2 \mathrm{~min}, 8000$ r.p.m.) and plasmid DNA was separated in NucleoSpin Plasmid columns (Macherey-Nagel (Germany) in accordance with the protocol of the manufacturing company. Concentration of the separated DNA was determined spectrophotometrically $(12.8 \mu \mathrm{g} / \mathrm{ml}$ for P08Co and 35 $\mu \mathrm{g} / \mathrm{ml}$ for P02Cr).

The Escherichia coli JM103 and E.coli XL1 Blue competent cells were prepared in accordance with the protocol [11]. Transformation of E. coli was performed using the standard method [11]. After transformation the bacterial suspension was inoculated on nutrient agar with the selective agent (5 $\mathrm{g} / \mathrm{l} \mathrm{Cr}(\mathrm{VI})$ or $0.5 \mathrm{~g} / 1 \mathrm{Co}^{2+}$ during transformation with $\mathrm{P} 02 \mathrm{Cr}$ and $\mathrm{P} 08 \mathrm{Co}$ plasmids, as well as on medium without selection. Besides, the non-transformed strains of E. coli were cultivated as a control under the similar conditions (with selection and without it).

\section{RESULTS AND DISCUSSION}

Resistance to antibiotics of bacteria from different taxonomic groups, isolated from extreme ecosystems, was compared. Phylogenic analysis and properties of these strains were described before [4-6, $8,9,12]$.

Antibiotics with different mechanisms of action were used for evaluation of the sensitivity to antibiotics. We used antibiotics - inhibitors of microorganisms cell wall (ampicillin, oxacillin, vancomycin, imipenem), inhibitors of protein synthesis at ribosome level (tetracycline, chloramphenicol, lincomycin, gentamycin, oleandomycin) and RNA polymerase inhibitors (rifampicin).

Pigmented strain, isolated from rocky lichen of Galindez island - Rhodococcus fascians $181 \mathrm{n} 3$ (orange pigment), Sporosarcina aquamarina $188 \mathrm{n} 2$ (brown pigment), as well as Sporosarcina aquamarina $188 \mathrm{n} 2$ and Staphylococcus epidermidis 190n1 pigmentless strain were found to be sensitive to all studied antibiotics. Strains Microbacterium foliorum $181 \mathrm{n} 2$ (yellow pigment) and Brevundimonas vesicularis 182n1 (pink pigment) were sensitive to the majority of antibiotics with the exception of Microbacterium foliorum 181n2 (yellow pigment) and Brevundimonas vesicularis $182 \mathrm{n} 1$ (pink pigment) strains were sensitive to the majority of antibiotics with the exception of ampicillin, oxacillin and imipenem. At the same time Pseudomonas fluorescens 180n1 and Rothia sp.190n2 strains demonstrated high level of resistance to the studied antibiotics (Table 1).

Analysis of sensitivity to antibiotics of strains isolated from soil samples of biogeographic range showed the following results. M. luteus 3201 was sensitive to all antibiotics tested, E.hormaechei 3202, B. antarcticum 3204, P.barcinonensis 3225 strains were resistant only to oxacillin and oleandomycin. Pseudomonas fluorescens 180n1, Rothia sp.190n2 and Microbacterium trichothecenolyticum 3208 strains showed high level of resistance (Table).

Thus, from 13 strains, isolated from extreme Antarctic ecosystems, Pseudomonas fluorescens 180n1, Rothia sp.190n2 and Microbacterium trichothecenolyticum 3208 had high resistance to antibiotics.

It is possible to presume that the revealed resistance to antibiotics of studied strains is caused by the extreme conditions under which the microorganisms of this ecosystem exist. They include high level of UV radiation as a mutagenic factor, desiccation and sharp temperature fluctuations. Miller et al. [13] did not associate antibiotic resistance of Antarctic microorganisms with plasmids and consider spontaneous mutations in the structural genes to be the cause of this resistance. According to the authors, antibiotic resistance of microorganisms can also be caused by human factors and depend on the temperature sensitivity. However, one can not exclude the likelihood that increased resistance to antibiotics occurs due plasmid genes localization.

It is also known that the resistance to antibiotics can correlate with the resistance to toxic metals [14, 
15]. Particularly, Antarctic microorganisms which are resistant to chloramphenicol, ampicillin, streptomycin, tetracycline and kanamycin as well as to metal toxic compounds $\left(\mathrm{K}_{2} \mathrm{CrO}_{4}, \mathrm{CdCl}_{2}, \mathrm{ZnCl}_{2}\right.$ и $\mathrm{HgCl}_{2}$ ) were isolated. This resistance can also be coded in some cases by plasmid genes [16-18].

In our experiments $E$. hormaechei 3202 and $M$. trichothecenolyticum 3208 strains were used for studying the nature of Antarctic microorganism resistance to toxic metals and antibiotics. These strains are relevantly highly resistant to $\mathrm{Cr}(\mathrm{VI})$ and
$\mathrm{Co}^{2+}$ compounds [6]. It was found out that both strains had the plasmids with a size more than $20 \mathrm{~kb}$. We transfered this plasmid to E.coli XL1Blue and E.coli JM103 strains which were originally sensitive to $\mathrm{Cr}(\mathrm{VI})$ and $\mathrm{Co}^{2+}$. Colonies resistant to the mentioned metals were obtained after the transformation of the bacteria. Moreover, the transformed $E$. coli bacteria became resistant to lincomycin. That is why the results obtained testify for a plasmid nature of the resistance of some studied microorganisms both to metals and antibiotics.

Table 1 - Sensitivity of Chemoorganotrophic Bacteria Isolated From Cliff Lichens and Soil Samples of Galindez Island to broad antibiotics spectrum

\begin{tabular}{|c|c|c|c|c|c|c|c|c|c|c|c|c|c|c|c|}
\hline $\begin{array}{l}\text { Genus, } \\
\text { Species }\end{array}$ & 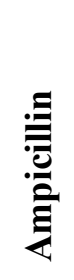 & 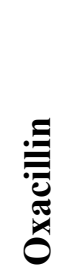 & 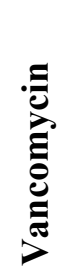 & Uే & 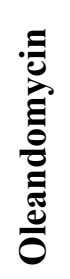 & & 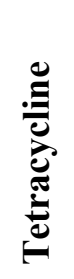 & 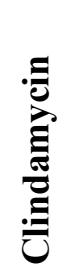 & 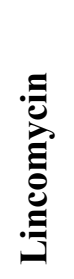 & 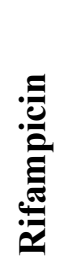 & 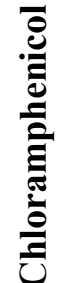 & 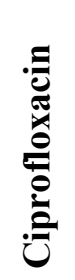 & 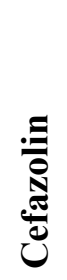 & 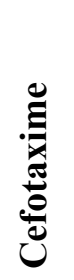 & 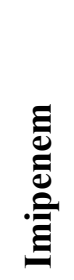 \\
\hline & \multicolumn{15}{|c|}{ Growth inhibition zone around the disk $(\mathrm{mm})$} \\
\hline $\begin{array}{l}\text { Pseudomonas } \\
\text { fluorescens } 180 \mathrm{n} 1\end{array}$ & 6 & 6 & 6 & 24 & 6 & 6 & 6 & 6 & 6 & 14 & 7 & 44 & 6 & 6 & 6 \\
\hline $\begin{array}{l}\text { Microbacterium } \\
\text { foliorum } 181 \mathrm{n} 2\end{array}$ & 30 & 6 & 24 & 17 & 40 & 50 & 22 & 34 & 30 & 42 & 36 & 30 & 18 & 40 & 6 \\
\hline $\begin{array}{l}\text { Rhodococcus } \\
\text { fascians } 181 \mathrm{n} 3\end{array}$ & 20 & 21 & 36 & 28 & 16 & 36 & 30 & 28 & 30 & 44 & 32 & 42 & 40 & 31 & 56 \\
\hline $\begin{array}{l}\text { Sporosarcina } \\
\text { aquamarina } 182 \mathrm{n} 1\end{array}$ & 45 & 42 & 45 & 45 & 40 & 30 & 28 & 6 & 24 & 40 & 28 & 30 & 45 & 22 & 45 \\
\hline $\begin{array}{l}\text { Brevundimonas } \\
\text { vesicularis } 187 \mathrm{n} 3\end{array}$ & 6 & 6 & 10 & 30 & 38 & 48 & 48 & 30 & 10 & 48 & 46 & 48 & 6 & 52 & 30 \\
\hline $\begin{array}{l}\text { Sporosarcina } \\
\text { aquamarina } 188 \mathrm{n} 2\end{array}$ & 52 & 40 & 42 & 50 & 41 & 26 & 30 & 6 & 25 & 40 & 25 & 40 & 40 & 36 & 40 \\
\hline $\begin{array}{l}\text { Staphylococcus sp. } \\
90 \mathrm{n} 1\end{array}$ & 40 & 45 & 45 & 42 & 45 & 42 & 40 & 40 & 40 & 45 & 40 & 41 & 45 & 31 & 45 \\
\hline Rothia sp. 190n2 & 6 & 6 & 6 & 30 & 6 & 30 & 6 & 6 & 6 & 24 & 14 & 32 & 6 & 6 & 6 \\
\hline $\begin{array}{l}\text { Micrococcus luteus } \\
3201\end{array}$ & 22 & 26 & 32 & 34 & 40 & 50 & 55 & 58 & 50 & 60 & 50 & 42 & 44 & 46 & 50 \\
\hline $\begin{array}{l}\text { Enterobacter } \\
\text { hormaechei } 3202\end{array}$ & 24 & 6 & 32 & 26 & 35 & 30 & 40 & 40 & 40 & 38 & 30 & 35 & 45 & 30 & 38 \\
\hline $\begin{array}{l}\text { Brevibacterium } \\
\text { antarcticum } 3204\end{array}$ & 6 & 6 & 36 & 36 & 30 & 25 & 56 & 52 & 20 & 50 & 30 & 36 & 28 & 38 & 28 \\
\hline $\begin{array}{l}\text { Microbacterium } \\
\text { trichothecenolyticu } \\
\text { m } 3208\end{array}$ & 6 & 6 & 22 & 20 & 6 & 6 & 6 & 6 & 6 & 16 & 14 & 37 & 6 & 26 & 30 \\
\hline $\begin{array}{l}\text { Paenibacillus } \\
\text { barcinonensis } 3225\end{array}$ & 25 & 34 & 28 & 36 & 0 & 12 & 40 & 44 & 32 & 18 & 32 & 34 & 32 & 32 & 48 \\
\hline
\end{tabular}




\section{CONCLUSION}

Resistance to antibiotics of bacteria from different taxonomic groups, isolated from extreme ecosystems, was compared. Pseudomonas antarctica and Rothia sp. strains, isolated from rocky lichen of Antarctic Galindez Island were highly resistant to the antibiotics studied. Thus, pigmented strains Rhodococcus fascians $18 \ln 3$ (orange pigment), Sporosarcina aquamarina 188n2 (brown pigment) as well as Staphylococcus epidermidis 190n1 pigmentless strains were found to be sensitive to all studied antibiotics. E.hormaeche 3202, M. richothecenolyticum 3208, Rothia sp. 190n2 strains growth demonstrated correlation between antibiotic resistance and toxic metal resistance.

We have confirmed that microorganisms isolated from natural ecosystems demonstrated in some cases the resistance to antibiotics. Studying of the nature of these strains resistance to toxic metals and antibiotics indicated plasmid localization of genes, coding resistance to $\mathrm{Cr}$ (VI) and $\mathrm{Co}^{2+}$. Demonstrated resistance of microorganisms isolated from «ecologically pure» and non-contaminated by anthropogenic factors ecosystems to antibiotics and toxic metals [6] and is fundamentally new data which testify the phenomenon of simultaneous resistance of microbial communities to different extremal factors.

\section{References}

1. Lo Giudice A., P. Casella, V. Bruni, L. Michaud, R.V. Miller, K. Gammon, M.J. Day, Response of bacterial isolates from Antarctic shallow sediments towards heavy metals, antibiotics and polychlorinated biphenyls, Ecotoxicol., Vol. 22, 2013, 240-250.

2. De Souza M.J., S.Nair, P.A. Loka Bharathi, D. Chandramohan, Metal and antibiotic-resistance in psychrotrophic bacteria from Antarctic Marine waters. Ecotoxicol., Vol. 15, 2006, 379-384.

3. Tewari S., P.W. Ramteke, M. Tripathi, Shailendra Kumar, Satyendra Kumar Garg, Plasmid mediated transfer of antibiotic resistance and heavy metal tolerance in thermotolerant water borne coliforms, African J. Microbiol Res, Vol. 7, 2013, 130-136.

4. Romanovskaya V.A., A.B. Tashyrev, S.O. Shilin, N.A. Chernaya, P.V. Rokitko, A.S. Levishko, Resistance of antarctic microorganisms to UV radiation, Mikrobiol. Zhurnal, Vol. 73, 2011, 3-8.

5. Romanovskaya V., A.Tashyrev, S.Shilin, G.Gladka, Distribution of psychrophilic microorganisms in terrestrial biotopes of Antarctic Region, Mikrobiol. zhurnal, Vol. 74, 2012, 3-8.
6. Tashyrev A.B., P.V. Rokitko, A.S. Levishko, V.A. Romanovska, A.A. Tashyreva, Resistance to toxic metals of chemoorganotrophic bacteria isolated from Antarctic cliffs, Mikrobiol. Zhurnal, Vol. 74, 2012, 3-7.

7. Vasileva-Tonkova E, V. Romanovskaya, G. Gladka, D. Gouliamova, I. Tomova, M. StoilovaDisheva, O.Tashyrev, Ecophysiological properties of cultivable heterotrophic bacteria and yeasts dominating in phytocenoses of Galindez Island, maritime Antarctica,World J Microbiol Biotechnol., Vol. 30, 2014, 1387-1398.

8. Tashyrev O.B., N.A. Matvieieva, V.A. Romanovskaya, A.O. Tashyreva, P.V. Rokitko Polyresistance and superresistance of Antarctic microorganisms to heavy metals, Reports of the National Academy of Sciences of Ukraine, Vol. 11, 2007, 170-175.

9. Romanovskaya V.A., V.V. Parfenova, N.L. Belkova, E.V. Sukhanova, G.V. Gladka, A.A. Tashyreva, Phylogenetic analysis of bacteria of extreme ecosystems, Mikrobiol. Zhurnal, Vol. 76, 2014, 3-10.

10. Vandepitte J., K. Engback, P. Piot, C.C.Heuck Basic Laboratory Procedures in Clinical Bacteriology. World Health Organization, 2003, 175 p.

11. Maniatis T., E.F. Fritsch, J.Sambrook, Molecular cloning: a laboratory manual. Cold Spring Harbor, N.Y. : Cold Spring Harbor Laboratory, 1982, $545 \mathrm{p}$.

12. Tashyreva A.A., G.O.Iutynska, O.B. Tashyrev Effect of cultivation parameters of Antarctic strains Enterobacter hormaechei and Brevibacterium antarcticum on resistance to copper (II) ions, Mikrobiol. zhurnal, Vol. 71, 2009, 3-8.

13. Miller R.V., K. Gammon, M. J. Day, Antibiotic resistance among bacteria isolated from seawater and penguin faecal samples collected near Palmer Station, Antarctica, Can. J Microbiol., Vol. 55, 2009, 37-45.

14. Shakibaie M. Plasmid mediated metal and antibiotic resistance in Pseudomonas aeruginosa strains isolated from burn petients, MJIRI, Vol.16, 2002, 159163.

15. Wright M.S., G.L. Peltier, R. Stepanauskas, J.V. McArthur, Bacterial tolerances to metals and antibiotics in metal-contaminated and reference streams FEMS Microbiol. Ecol., Vol. 58, 2006, 293-302.

16. Thavasi R., K. Aparnadevi, S. Jayalakshmi, T. Balasubramanian, Plasmid mediated antibiotic resistance in marine bacteria. J. Environmental Biol., Vol. 28, 2007, 617-621.

17. Baya A.M., P.R. Brayton, V.L. Brown, D.J. Grimes, E. Russek-Cohen, R.R. Colwell, Coincident plasmids and antimicrobial resistance in marine bacteria isolated from polluted and unpolluted Atlantic Ocean 
samples, Appl. Environ. Microbiol, Vol. 51, 1986, $1285-1292$.

Staphylococcus spp., Arch Med Res, Vol. 34, 2003, 130-136.

18. Ug A., O. Ceylan, Occurrence of resistance to

antibiotics, metals, and plasmids in clinical strains of

\title{
ИЗСЛЕДВАНЕ НА РЕЗИСТЕНТНОСТТА КЪМ АНТИБИОТИЦИ НА МИКРООРГАНИЗМИ, ИЗОЛИРАНИ ОТ АНТАРКТИЧЕСКИ СКАЛИ И ЧЕРНОМОРСКИ ДЪННИ УТАЙКИ
}

\author{
Н. А. Матвиейева, Л. Н. Чуркина, А.М. Шаховски, С.В. Кадурин, А.Б. Таширев
}

Резюме. Сравнява се резистентността към антибиотици на бактерии, изолирани от екстремни екосистеми. Pseudomonas antarctica и Rothia sp., щамове, изолирани от скален лишей от антарктическия остров Galindez са силно резистентни към антибиотици. За щамовете Rhodococcus fascians 181n3, Sporosarcina aquamarina 188n2 и Staphylococcus epidermidis 190n1 беше установено, че са чувствителни към всички изследвани антибиотици. Плазмидната локализация на гени, кодиращи резистентност към $\mathrm{Cr}(\mathrm{VI})$ и $\mathrm{Co}^{2+}$ е определена. Връзката на устойчивост на микроорганизмите, изолирани от «екологично чиста» екосистема към антибиотици е показано в това изследване и заедно с устойчивостта на тези микроорганизми към токсични метали, посочена от нас порано са принципно нови данни, които свидетелстват за явлението едновременна устойчивост на микробно съобщество към различни екстремални фактори.

Ключови думи: микроорганизми, антарктически скали, антибиотична резистентност, устойчивост към токсични метали

\section{N.A. Matvieieva, PhD,}

Head of Laboratory of adaptational biotechnology, Institute of Cell Biology and Genetic Engineering of NAS of Ukraine

\section{L.N. Churkina, PhD,}

Senior Scientist, D.K. Zabolotny Institute of Microbiology and Virology of NAS of Ukraine

\section{A.M. Shakhovsky,}

Scientist, Institute of Cell Biology and Genetic Engineering of NAS of Ukraine

\section{S.V. Kadurin,}

Taras Shevchenko National University of Kyiv

\section{A.B. Tashyrev, Dr Sci}

Head of the Department of biology of extremophilic microorganisms

D.K. Zabolotny Institute of Microbiology and Virology of NAS of Ukraine

Corresponding author. Email: tach2007@ukr.net 